\title{
Las fiestas de moros y cristianos en la Alpujarra granadina
}

La función o representación conocida como fiestas de moros y cristianos es una celebración muy extendida en Andalucía, fundamentalmente en la zona más orienta (Almería y Granada), aunque también encontramos ejemplos en las provincias de Jaén, Málaga o Cádiz. Estas funciones de teatro popular dirigen la mirada hacia un pasado histórico mediante la recreación de diferentes escenas que aluden a enfrentamientos por un territorio donde la imagen patronal adquiere una especial significación.

Dentro de los lugares donde esta celebración ha tenido mayor importancia se encuentra la Alpujarra granadina, y prueba de ello son las representaciones que tienen lugar en poblaciones como Albondón, Bubión, Cherín (Ugijar), Juviles, Picena o Trevélez.

Insertos en el ciclo festivo anual, estas manifestaciones se desarrollan durante todo el año, siendo el periodo estival el que concentra un mayor número de representaciones, hecho que coincide con la llegada de numerosos emigrantes a sus lugares de origen y la celebración de las fiestas patronales. En Albondón, por ejemplo, la representación de moros y cristianos tiene lugar a finales de agosto coincidiendo con las fiestas en honor a San Luis Rey de Francia y en Trevélez, en junio, con la festividad de San Antonio.

En el desarrollo del ritual adquieren protagonismo los diferentes personajes que suelen aparecer en esta representación, entre los cuales destacan el rey, el general, el espía, el guerrero y el abanderado, y las tropas de cada uno de los bandos participantes. Junto a estos podemos encontrar otras figuras que dependen en gran medida de las tradiciones locales vinculadas a esta expresión.

La conservación de los textos recitados, conocidos como "relaciones", han sido trasmitidos por medio de la tradición oral, aunque también podemos encontrar algunos documentos escritos, tal y como sucede en Tímar, fechado en mil novecientos veintitrés, o el de Juviles, fechado en mil novecientos cuarenta y cinco.

Para la escenificación de los diferentes actos se suelen preparar varios espacios centrales de la población, siendo habitual el uso de la plaza como lugar en el que transcurren los principales acontecimientos. Normalmente la "batalla" entre "moros y cristianos" se desarrolla en dos partes diferenciadas: una primera, en la que el bando moro resulta vencedor, y una segunda en la que los cristianos consiguen arrebatar la imagen patronal y salir victoriosos de este "enfrentamiento".

La imagen patronal, presente en el acto o representada mediante algún símbolo, el castillo construido para el tiempo ritual, las indumentarias, los caballos y otros elementos conforman contextos de enorme riqueza que expresan imaginarios colectivos de indudable interés.

La intermitencia y desaparición de este tipo de representaciones en esta comarca y otras poblaciones andaluzas se convierte en una característica compartida por la mayoría de las localidades donde ésta se lleva a cabo. Este rasgo común evidencia, entre otros aspectos, las transformaciones socioeconómicas que las poblaciones han ido sufriendo en las últimas décadas y pone de manifiesto la necesidad de investigaciones que se acerquen al análisis e interpretación de las mismas. Con relación a esto último debemos mencionar la tarea desarrollada por la Consejería de Cultura quien, a través de las Delegaciones Provinciales de Almería y Jaén, está elaborando la documentación técnica necesaria para la inscripción de estas expresiones rituales en el Catálogo General del Patrimonio Histórico Andaluz. 